\title{
24
}

\section{Information Technology and the Management of Instructional Programs: Meeting the Challenge of Curriculum-Time Compression in Schools}

\author{
James E. Bruno \\ Graduate School of Education, University of California, Los Angeles, \\ 405 Hilgard Avenue, Los Angeles, California, U.S.A.
}

\begin{abstract}
Presently there exists an important need for employing information technologies to assist educators in the complex task of monitoring and supporting instructional programs. Using technology to enhance a comprehensive low cost and mass scale formative evaluation of student attainment is one mechanism for achieving this elusive goal. Recent global trends toward compressing school curricula to include more advanced academic topics taught at lower levels of instruction (elementary, secondary, college), or teaching the same topics in shorter time periods has served to underscore the need for technology based instructional support. This paper reports the results of recent research with a technology based, formative evaluation procedure called Information Referenced Testing (IRT). With information technologies, not only is one able to better assess individual student attainment, but to simultaneously better assess the quality of the instructional program itself.
\end{abstract}

Keyword Codes: J.4; H.4.0; K.4.1

Keywords: Computer Applications; Information Systems; Computers and Society; Social and Behavioral Sciences; Applications General; Public Policy Issues

\section{INTRODUCTION}

In the near future, the role of information technologies will expand from one of providing information for resource allocation, budgeting, and accounting, to one of providing information for instructional support to promote student learning.

The availability of networked, low cost microcomputer information processing and newly developed information acquiring systems will soon merge with sophisticated optical scan technologies to assess, monitor, and prescribe detailed learning plans of action for the individual student, the teacher, and the school administrator. 
Educational management in this more comprehensive view of instructional support will be both individual student centered as well as group centered. An impetus to merge these two technologies (information processing with information acquiring) has been provided by the enormous amounts of curricula compression that has occurred in schooling over the past two decades. The global phenomenon of curriculum-time compression, where formerly advanced subjects and topics are taught at lower levels of instruction (such as elementary, middle, and high school) and more topics are taught in shorter time periods, will place enormous strains on already overworked instructional support systems in educational organizations. Enhancing the ability to teach more in less time and preparing students for more advanced levels of instruction will, therefore, be important objectives for these technology based instructional support systems.

In order to respond to the curricula-time compression phenomenon, schools, especially elite private schools, are merely selecting students at higher and higher levels of academic attainment. Other schools, mainly suburban public schools, are essentially "dumbing down" instructional programs because students are simply not able to keep up with the rapid pace required to succeed in these compressed curriculums. Some schools, such as inner city schools in large urban areas, have little or no instructional support for their students either from the home or from technology. These schools have simply given up and have placed an entire cohort of students "at risk" in their subsequent education by warehousing their students-especially in the areas of science and mathematics.

In order for schools to effectively respond to the curricula-time compression phenomenon, instructional support has to merge with information acquiring and information processing technologies to provide a more enhanced and comprehensive formative evaluation of the instructional program.

In short, in order to respond to curriculum-time compression, more sophisticated information technologies for educational management (ITEM) schemes have to be developed. These schemes might take the general form of 1) expanding and relying on information technologies to service or "process" the information needed to support instructional programs, 2) shifting emphasis on student assessment from "summative" evaluation to enhanced "formative" evaluation via sophisticated information "acquiring" technologies, and 3) developing the reliability, maintainability, and economic viability of combination information processing and acquiring technologies.

A principle focus of this paper, is directed at the information acquisition technologies or technology based formative evaluation procedures for instructional support and educational management. Specifically, this paper focuses on "information referenced" types of student assessment procedures and how these procedures can be placed into a comprehensive formative evaluation system in an educational setting to support instruction. These types of technology based formative evaluation procedures can then be used to provide specific diagnostic information to the instructional management 
TRIAD (student, teacher, administrator) in a format needed to enhance overall educational management.

The centerpiece for this type of formative evaluation technology is 1) the instructional audit of knowledge or information, 2) a scoring system to acquire student attainment information that is referenced to an information quality assessment standard, and 3) a technology to process this information and place the results into a format that is needed for instructional support and educational management.

In summary, on two levels - the ability to acquire attainment information and the ability to process information-Information Technologies for Educational Management (ITEM) can become an important instrument that can be used as an effective response to the growing phenomenon of curriculatime compression.

\section{INFORMATION ACQUIRING TECHNOLOGIES FOR INSTRUCTIONAL SUPPORT}

In order to "acquire" attainment information for purposes of enhanced formative evaluation and instructional support, a different type of information acquiring technology is needed. This type of technology has to be able to assess student attainment, not with a one dimensional or recognition only (rightwrong, or RW) type of test scoring system, but with a two dimensional (recognition plus confidence in that recognition) and information referenced (misinformed, uninformed, partially informed, and informed) type of scoring system. In essence, enhanced formative evaluation requires that the information "quality" of students be assessed.

Extensions of two dimensional types of test scoring systems to make them compatible with modern optical scan technologies and to specifically generate formative evaluation feedback and reports to the instructional management TRIAD have recently been placed into an Information Referenced Testing (IRT) format [Bruno, 1987].

Applications of the IRT procedure to urban inner city student instructional audits [Bruno, 1988] and direct research comparisons between RW and IRT formats [Bruno, 1989] have also appeared in the educational research literature.

IRT research and technology based formative evaluation has also been extended to other important areas in the research of Baxter [1991, 1993], at risk inner city student formative evaluation at large inner city elementary schools and Klentschy [1992], for supporting accelerated learning in classrooms. 


\begin{tabular}{|c|c|c|c|c|c|}
\hline (1) & & & & & IDON'T KNOW \\
\hline (4) 0 & ๑ & (ㄱ) & (3) & (3) & 0 \\
\hline () 0 & ๑ & (2) & (3) & (2) & 0 \\
\hline (4) 0 & ๑ & (2) & (2) & (3) & 0 \\
\hline (๑) 0 & ○ & (2) & (1) & (2) & 0 \\
\hline (1) & ○ & (1) & (3) & () & 0 \\
\hline (1) () & (๑) & (ㄱ) & (2) & (2) & 0 \\
\hline (๑) 0 & ๑ & (ㄱ) & (1) & (2) & 0 \\
\hline (1) (0 & ○ & () & (2) & (3) & 0 \\
\hline (1) 0 & ๑ & (강 & (3) & (3) & 0 \\
\hline (1) () & ๑ & (1) & (2) & (3) & 0 \\
\hline (2) (8) & $\odot$ & () & (2) & (3) & 0 \\
\hline (อ) & ๑ & (1) & (3) & (3) & 0 \\
\hline () 0 & ○ & (2) & (3) & (3) & 0 \\
\hline (1) 0 & ๑ & 궁 & (3) & (3) & 0 \\
\hline
\end{tabular}

- Do NOT use ink or ballpoint pens.

- Make heavy black marks that fill the circle

completely. See example below.

IAM NOT SURE IDON'T KNOW

(1) - $\bigcirc)$

- Erase cleanly any answer you wish to change.

- Make no stray marks on the answer sheet.

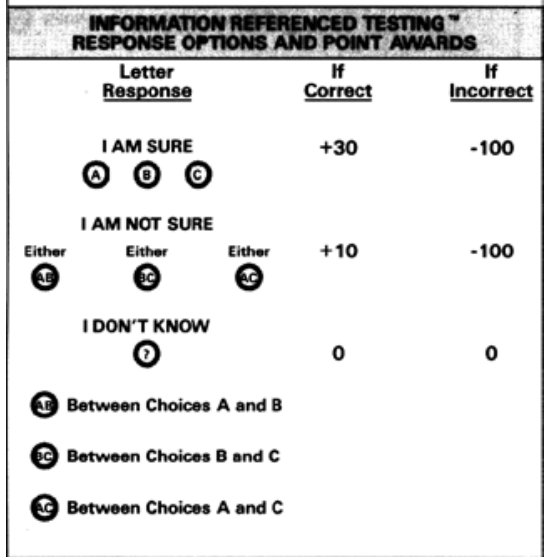

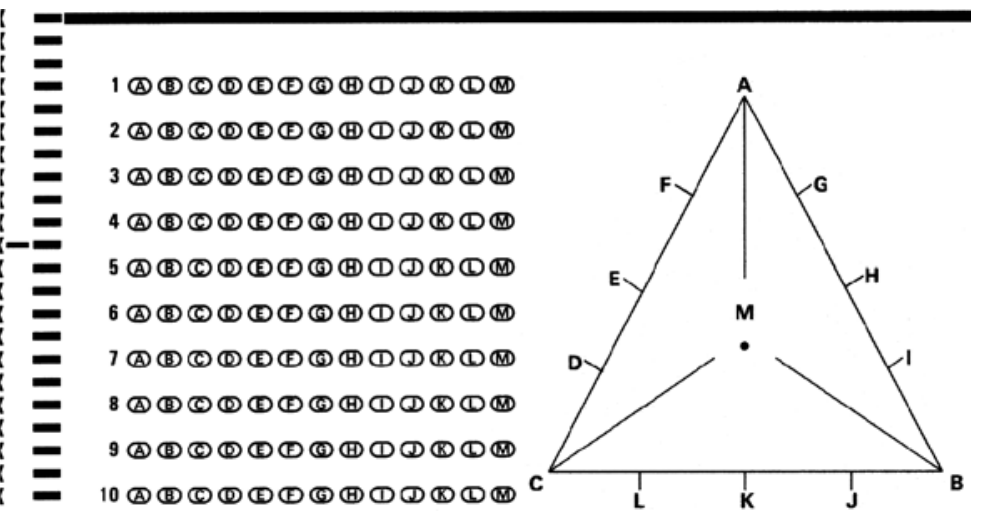

Figure 1. Optical scan answer sheets needed to support technology based formative evaluation 


\section{INFORMATION FOR THE EDUCATIONAL MANAGEMENT TRIAD: THE STUDENT}

The Individual Education Plan (IEP) is the actual diagnostic formative evaluation "audit" of the student information base that is needed for instructional support. The audit concept can be used by the teacher (parent, employer) to provide a plan of action to keep the student (employee) "on line" with regard to currently needed levels of reliable information. This IRT report called the IEP, essentially articulates the instructional program to students (and parents) and is used solely for purposes of "student centered" formative evaluation (portions of IEPs can be found in Figure $2 \mathrm{a}$-poor information quality and $2 \mathrm{~b}-$ good information quality).

MISINFORMATION_-CONCEPTS WHERE YOU WERE SURE OF AN ANSWER BUT WERE WRONG - HAVE INSTRUCTOR EXPLAIN WHY THE ANSWER YOU THOUGHT WAS CORRECT WAS WRONG AND WHY ANOTHER ANSWER WAS
CORRECT

$\begin{array}{cc}\text { TEST ITEM (INF STATE) } & \text { DESCRIPTION INSTRUCTIONAL CROSS REFERENCE } \\ 1 \mathrm{M} & \text { TO USE PLACE VALUE CONCEPTS } 4 \text { DIGIT NUMBERS } \\ \cdot & \text { ADDISON WESSLEY 4TH GRADE CHAPTER } 2 \text { P. 26-27 }\end{array}$

EXAMINEE UNINFORMED (LACKS INFORMATION) RESPONSES

CONCEPTS YOU SAID YOU DIDN'T KNOW-HAVE YOUR INSTRUCTOR EXPLAIN THESE CONCEPTS TO YOU

TEST ITEM (INF STATE) DESCRIPTION INSTRUCTIONAL CROSS REFERENCE

$2 U$ TO USE PLACE VALUE TO READ UP TO 6 DIGIT NUMBERS

ADDISON WESSLEY 4TH GRADE CHAPTER 2 P. 26-27

PERCENT INFORMED, 0.33; PERCENT UNINF, 0.37; PERCENT PART INF, 0.27; PERCENT MISINF, 0.03;

PERCENT RIGHT WITH RW, 0.0; PERCENT WRONG WITH RW, 0.0

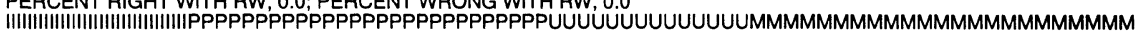

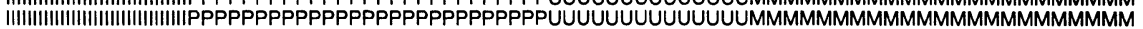

Figure 2a. Portion of an IEP of a student with poor information quality (Note high levels of misinformation)

\section{EXAMINEE FULLY INFORMED ITEMS ON EXAMINATION}

CONCEPTS WHERE YOU WERE SURE OF THE ANSWER AND WERE CORRECT-YOU HAVE RELIABLE INFORMATION IN THESE AREAS - KEEP UP THE GOOD WORK

$\begin{array}{cc}\text { TEST ITEM (INF STATE) } & \text { DESCRIPTION INSTRUCTIONAL CROSS REFERENCE } \\ 11 & \text { ESTIMATE SUMS BY ROUNDING TO NEAREST TEN, HUNDRED } \\ \text { ADDISON WESSLEY 4TH GRADE CHAPTER } 3 \text { P. } 56-59\end{array}$

PERCENT INFORMED, 0.87; PERCENT UNINF, 0.10; PERCENT PART INF, 0.0; PERCENT MISINF, 0.03 ; PERCENT RIGHT WITH RW, 0.0; PERCENT WRONG WITH RW, 0.0

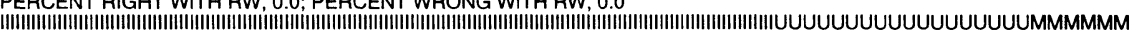

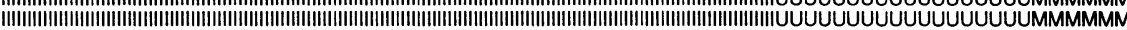

Figure 2b. Portion of an IEP of a student with good information quality (Note high levels of reliable information) 


\section{INFORMATION FOR THE EDUCATIONAL MANAGEMENT TRIAD: THE TEACHER}

The CINP that is derived from the technology based formative evaluation procedure clusters IEPs across all students for a particular classroom or instructional unit. It is designed to provide, in a classroom setting, instructional feedback to the teacher that ranks the most "common" misinformed concepts, the most common uninformed concepts, etc., for a specific classroom of students. Note how teachers can use this IRT formative evaluation report information to prepare class reviews and to fine tune the school curricula to the exact and common information needs of a particular classroom of students (Figure 3 ).

MISINFORMED EXAMINATION ITEMS FOR YOUR EXAMINEES-YOUR EXAMINEES HAVE WRONG INFORMATION IN THESE CONCEPT AREAS

HAVE WORKSHOP COORDINATOR DEVELOP INSTRUCTIONAL MATERIALS-DEMONSTRATE MISCONCEPTIONSFOLLOW THIS WITH ACCURATE INFORMATION

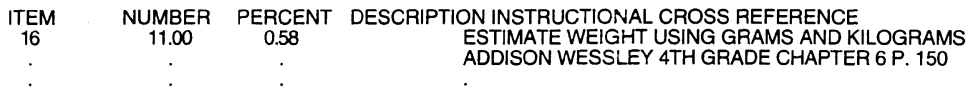

UNINFORMED TEST ITEMS ON THE EXAMINATION-EXAMINEES GENERALLY LACK INFORMATION IN THESE CONCEPT AREAS-BASIC INSTRUCTIONAL MATERIALS NEEDED IN THIS AREA

$\begin{array}{cccc}\text { ITEM } & \text { NUMBER } & \text { PERCENT } & \text { DESCRIPTION INSTRUCTIONAL CROSS REFERENCE } \\ \mathbf{2} & 11.00 & 0.58 & \text { MAP TO SOLVE PROBLEMS (DECIMALS) } \\ . & . & . & \text { ADDISON WESSLEY 4TH GRADE CHAPTER 14 P. } 354-355 \\ . & . & . & \cdot\end{array}$

PART INFORMED AREAS

YOUR EXAMINEES HAVE INCOMPLETE OR UNSTABLE INFORMATION IN THESE CONCEPT AREASINSTRUCTIONAL MATERIALS ARE INCOMPLETE OR LACK SUFFICIENT DETAIL

$\begin{array}{cccc}\text { ITEM } & \text { NUMBER } & \text { PERCENT } & \text { DESCRIPTION INSTRUCTIONAL CROSS REFERENCE } \\ 17 & 6.00 & 0.32 & \text { ESTIMATE TEMPERATURE USING DEGREES CELSIUS } \\ . & . & . & \text { ADDISON WESSLEY 4TH GRADE CHAPTER } 14 \text { P. } 354-355\end{array}$

INFORMED CONCEPT AREAS

EXAMINEES GENERALLY HAVE REPLICABLE (ACCURATE AND CONFIDENT) INFORMATION IN THESE CONCEPT AREAS

WORKSHOP COORDINATORS SKIP OVER THESE CONCEPTS OR ADDRESS LIGHTLY

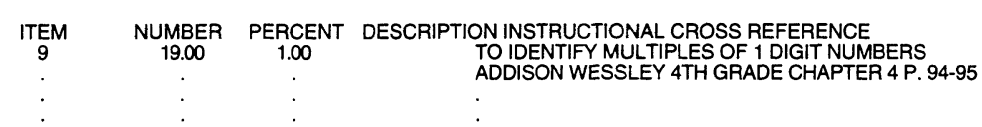

Figure 3. Portion of a Class Information Needs Profile (CINP) for a mathematics classroom 


\section{INFORMATION FOR THE EDUCATIONAL MANAGEMENT TRIAD: THE SCHOOL ADMINISTRATION}

The IRT procedure can also be used to generate reports that identify common information needs across all students and all instructional classroom units. The School (or System) Information Needs Profile (SINP) report is used to examine how instructional materials and teaching effectiveness (the signal) is being received by all students in a particular instructional program. This IRT report is used by educational administrative personnel to identify inordinate amounts of misinformation (suggesting the rewriting of instructional materials), lack of information (suggesting the developing of supplementary instructional materials), and partial information (suggesting the adding of greater clarity and comprehensiveness to instructional materials) in an instructional program (Figure 4).

MISINFORMED EXAMINATION ITEMS FOR YOUR EXAMINEES - YOUR EXAMINEES HAVE WRONG INFORMATION IN THESE CONCEPT AREAS HAVE WORKSHOP COORDINATOR DEVELOP INSTRUCTIONAL MATERIALSDEMONSTRATE MISCONCEPTIONS-FOLLOW THIS WITH ACCURATE INFORMATION

$\begin{array}{cccc}\text { ITEM } & \text { NUMBER } & \text { PERCENT } & \text { DESCRIPTION INSTRUCTIONAL CROSS REFERENCE } \\ 30 & 32.00 & 0.39 & \text { FIND DIFFERENCES OF DECIMALS THROUGH HUNDREDTHS } \\ . & . & . & \text { ADDISON WESSLEY 4TH GRADE CHAPTER } 14 \text { P. } 354-357\end{array}$

UNINFORMED TEST ITEMS-EXAMINEES GENERALLY LACK INFORMATION IN THESE CONCEPT AREAS-BASIC INSTRUCTION MATERIALS NEEDED IN THIS AREA

$\begin{array}{cccc}\text { ITEM } & \text { NUMBER } & \text { PERCENT } & \text { DESCRIPTION INSTRUCTIONAL CROSS REFERENCE } \\ 13 & 52.00 & 0.63 & \text { DIVIDE BY 2 DIGIT DIVISORS TO FIND } 1 \text { DIGIT QUOTIENTS } \\ : & : & : & \text { ADDISON WESSLEY 4TH GRADE CHAPTER } 13 \text { P. 322-323 } \\ : & : & : & :\end{array}$

PART INFORMED AREAS-YOUR EXAMINEES HAVE INCOMPLETE OR UNSTABLE INFORMATION IN THESE CONCEPT AREAS-THOROUGH REVIEW NEEDED - HAVE YOUR WORKSHOP COORDINATOR PREPARE A REVIEW

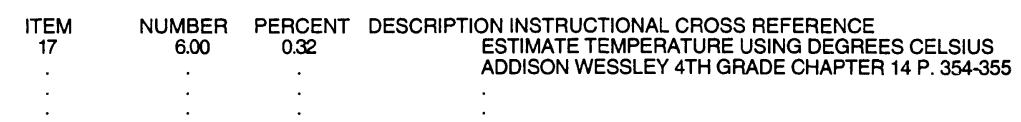

INFORMED CONCEPT AREAS-EXAMINEES GENERALLY HAVE REPLICABLE (ACCURATE AND CONFIDENT) INFORMATION IN THESE CONCEPT AREAS

WORKSHOP COORDINATORS SKIP OVER THESE CONCEPTS OR ADDRESS LIGHTLY

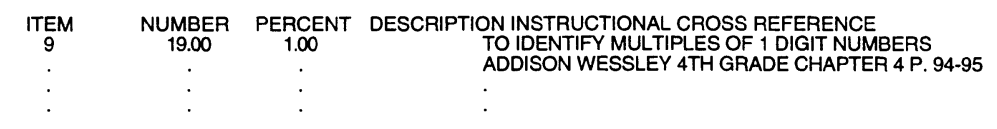

Figure 4. Portion of a School Information Needs Profile (SINP) in Mathematics across all classrooms at a given grade level 


\section{SUMMARY}

Evaluating students on an information quality attainment standard of being informed, partially informed, uninformed, and misinformed is better pedagogically aligned (review, instruction, re-education) to teacher needs and instructional support than either a percent correct score or a percentile score. More importantly, information referenced measures of the "quality" of student information, better align themselves to the information technologies that are needed for effective educational management via specific diagnostic plans of actions directed at students, teachers, and school administrators.

As presented earlier in this discussion, the IRT procedure is an enhanced formative evaluation procedure that is fully optically scannable and generates a variety of specific diagnostic reports for the instructional management TRIAD in educational organizations. These reports include 1) an IEP for each student (for purposes of formative evaluation), 2) a CINP provided for the teacher (for curriculum fine tuning), and 3) a SINP provided for the school administrator (resource allocation and curriculum design).

\section{REFERENCES}

1. Bruno, J. E. (1987). Using computers for instructional delivery and diagnosis of student learning in elementary schools. Journal of Computers in the Schools, Vol. 4, No. 2, pp. 117-134.

2. Bruno, J. E. (1988). The instructional audit in urban school settings: A descriptive policy analysis of instructional delivery using signal-receptor assessment theory and information referenced testing. The Urban Review, Vol. 20, No. 2, pp. 95-107.

3. Bruno, J. E. (1989). Monitoring the academic progress of low-achieving students: An analysis of right-wrong (RW) versus information referenced (MCW-APM) formative and summative procedures. Journal of Research and Development in Education, Vol. 22, No. 4, pp. 51-61.

4. Baxter, J. B. (1991). Information referenced testing for formative evaluation and self-assessment to support the elaboration and advancement of student thinking and learning. Paper presented at the Eighth International Conference on Technology and Education, Toronto, Canada.

5. Baxter, J. B. (1993). Formative evaluation and the self-assessment process to support instruction at inner. city schools. Unpublished doctoral dissertation, University of California, Los Angeles.

6. Klentschy, M. L. (1992). Supporting accelerated learning with information referenced testing. Ninth International Conference on Technology and Education, Paris, France, March 1992. 